\title{
Proper training and use of ultrasonography facilitates lumbar puncture
}

Geert-Jan van Geffen ${ }^{1,2}$, Rein Ketelaars ${ }^{1,2^{*}}$ (D) and Jörgen Bruhn ${ }^{1}$

\begin{abstract}
With great interest, we read the study of Line Dussourd et al. concluding that ultrasonography allows better identification of anatomical structures before performing a lumbar puncture. We cannot concur with the conclusions of the study because the authors did not visualize the conus medullaris directly, nor did they assess the individual intervertebral levels. In our commentary, we make some suggestions for improvement using ultrasound to locate the optimal site for a lumbar puncture. We do agree that neuraxial ultrasound is of great benefit for the performance of lumbar punctures. Proper training and applying the correct technique, however, is necessary for obtaining all benefits ultrasonography offers.
\end{abstract}

Keywords: Ultrasonography, Spinal puncture, Emergency service, Hospital, Emergency medicine

To the editor:

Sir,

With interest, we read the article of Dussourd et al. [1]. Although we agree with their conclusion that ultrasonography allows better identification of anatomical structures before lumbar puncture, we cannot concur with their statement that ultrasound identified the best lumbar puncture site under the conus medullaris. The authors did not visualize the conus medullaris directly, nor did they assess the individual intervertebral levels.

To improve the accuracy of intervertebral space identification in preparation for a lumbar puncture a preprocedure spinal ultrasound scan should be performed identifying the individual intervertebral levels. This may be performed by counting spinous processes or laminae upward from the sacrum. Using this method, ultrasound may accurately identify the correct intervertebral space in $76 \%$ of the cases [2].

Moreover, identifying a lumbar interlaminar space is not easy and it is hard to achieve competency in all aspects of spinal ultrasonography [3]. Trainees in anesthesiology were only considered competent after performing 60 supervised scans. Therefore, we doubt

\footnotetext{
* Correspondence: Rein.Ketelaars@Radboudumcnl

'Department of Anesthesiology, Pain and Palliative Medicine, Radboud university medical center, Nijmegen, The Netherlands

${ }^{2}$ Helicopter Emergency Medical Service, Lifeliner 3, Radboud university medical center, Nijmegen, The Netherlands
}

whether the participating emergency physicians obtained all necessary skills to successfully identify the correct lumbar intervertebral space after a training which did not exceed $30 \mathrm{~min}$.

Neuraxial ultrasound improves the efficacy of neuraxial techniques. A recent meta-analysis showed the combined risk ratio of technical failure in lumbar neuraxial procedures was 0.51 (95\% CI, 0.32-0.80) when ultrasound guidance is used compared to palpation. In addition, ultrasound guidance results in a lower number of needle passes required for success [4].

\section{Conclusions}

In conclusion, we do agree that neuraxial ultrasound is of great benefit for the performance of lumbar punctures. Proper training and applying the correct technique, however, is necessary for obtaining all benefits ultrasonography offers.

Geert-Jan van Geffen,

Rein Ketelaars,

Jörgen Bruhn.

\section{Acknowledgements}

Not applicable

Funding

No funding was received for this commentary. The department of anesthesiology employing all authors paid for the article processing charges. 


\section{Availability of data and materials}

Data sharing not applicable to this article as no datasets were generated or analyzed during the current study.

\section{Authors' contributions}

GJVG conceived the commentary. All three authors (GJVG; RK; JB) contributed equally to the writing of the manuscript. All authors read and approved the final manuscript.

\section{Ethics approval and consent to participate}

Not applicable

\section{Consent for publication}

Not applicable.

\section{Competing interests}

The authors declare that they have no competing interests.

\section{Publisher's Note}

Springer Nature remains neutral with regard to jurisdictional claims in published maps and institutional affiliations.

Received: 13 July 2017 Accepted: 11 December 2017

Published online: 20 December 2017

\section{References}

1. Dussourd L, Martinon B, Candille C, Paquier C, Wintenberger C, Dumanoir P, et al. Ultrasonography helps emergency physician identify the best lumbar puncture site under the conus medullaris. Scand I Trauma Resusc Emerg Med. 2017;25:60

2. Watson MJ, Evans S, Thorp JM. Could ultrasonography be used by an anaesthetist to identify a specified lumbar interspace before spinal anaesthesia? Br J Anaesth. 2003:90:509-11.

3. Deacon AJ, Melhuishi NS, Terblanche NC. CUSUM method for construction of trainee spinal ultrasound learning curves following standardised teaching. Anaesth Intensive Care. 2014;42:480-6.

4. Perlas A, Chaparro LE, Chin KJ. Lumbar Neuraxial ultrasound for spinal and epidural anesthesia: a systematic review and meta-analysis. Reg Anesth Pain Med. 2016:41:251-60.

Submit your next manuscript to BioMed Central and we will help you at every step:

- We accept pre-submission inquiries

- Our selector tool helps you to find the most relevant journal

- We provide round the clock customer support

- Convenient online submission

- Thorough peer review

- Inclusion in PubMed and all major indexing services

- Maximum visibility for your research

Submit your manuscript at www.biomedcentral.com/submit 